Journal of Industrial and Engineering System (JIES)

e-ISSN: 2722-7979

Vol. 1 No. 2, Hal 101 - 110

\title{
Pengaruh Faktor-Faktor Lingkungan Eksternal yang Menghambat Penggunaan E-Commerce pada UMKM Kerajinan di Kota Yogyakarta
}

\author{
Syifa Fitriani ${ }^{* 1}$, Melati Medinah ${ }^{2}$, Utaminingsih Linarti ${ }^{3}$ \\ Program Studi Teknik Industri Fakultas Teknik, Universitas Ahmad Dahlan \\ e-mail: ${ }^{* 1}$ syifa.fitriani@ie.uad.ac.id, ${ }^{2}$ melatimedinah@gmail.com , \\ ${ }^{3}$ utaminingsih.linarti@ie.uad.ac.id,
}

*Korespondensi: syifa.fitriani@ie.uad.ac.id

\begin{abstract}
Ecommerce is one of the ways used to develop the economy by marketing handicraft products online. Based on the classification of 1895 craft MSMEs in Yogyakarta which were only registered at the DISPERINDAG website as many as 453 so that there are still many who have not utilized the use of eCommerce in marketing their products. The Objective of this study are to determine external environmental factors that affect barriers to the use of e-Commerce in craft MSMEs and to determine the simultaneous influence on technological factors, consumer factors, competitor factors, and government policy factors. The data collection method was carried out by distributing questionnaires and interviews as many as 100 handicraft MSMEs in the city of Yogyakarta. The method of analysis in this study uses multiple linear regression calculations using SPSS 15.0 to see the influence between one variable and another. Based on the results of data research, the factors that influence the barriers to the use of e-Commerce in handicraft MSMEs in Yogyakarta City, seen from the coefficient, are the consumer factor of 2.721. Technological factors, competitors and government policies do not affect barriers to e-Commerce use. After testing simultaneously, it was found that the independent variables (technology, consumers, competitors and government policies) could explain the variance of the dependent variable, namely the barriers to using e-Commerce at Handicraft MSMEs in Yogyakarta City with a coefficient of determination of $11 \%$.
\end{abstract}

Key Word: e-Commerce, External Environment, MSMEs

\begin{abstract}
ABSTRAK
Ecommerce adalah salah satu cara yang digunakan untuk mengembangkan perekonomian dengan melakukan pemasaran produk kerajian secara online. Berdasarkan klasifikasi sebanyak 1895 pelaku UMKM kerajinan di Kota Yogyakarta yang baru terdaftar di website Dinas Perindustrian dan Perdagangan (DISPERINDAG) Kota Yogyakarta sebanyak 453 sehingga masih banyak yang belum memanfaatkan penggunaan e-Commerce dalam pemasaran produknya. Penelitian ini bertujuan untuk mengetahui faktor-faktor lingkungan eksternal yang mempengaruhi hambatan penggunaan $e$ Commerce pada UMKM kerajinan dan mengetahui pengaruh simultan terhadap faktor teknologi, faktor konsumen, faktor pesaing, dan faktor kebijakan pemerintah. Metode pengumpulan data dilakukan dengan melakukan penyebaran kuisioner dan wawancara sebanyak 100 UMKM kerajinan di Kota Yogyakarta. Metode analisis dalam penelitian ini menggunakan perhitungan regresi linier berganda menggunakan SPSS 15.0 untuk melihat pengaruh antara satu variabel dengan variabel lainnya. Berdasarkan hasil penelitian data, faktor yang berpengaruh terhadap hambatan penggunaan $e$ Commerce pada UMKM kerajinan di Kota Yogyakarta dilihat dari koefisiennya adalah faktor konsumen sebesar 2,721. Faktor teknologi, pesaing dan kebijakan pemerintah tidak berpengaruh terhadap hambatan penggunaan e-Commerce. Setelah dilakukan pengujian secara simultan didapatkan hasil bahwa variabel independen (teknologi, konsumen, pesaing dan kebijakan pemerintah) dapat menjelaskan variansi dari variabel dependen yaitu hambatan penggunaan e-Commerce pada UMKM Kerajinan di Kota Yogyakarta dengan nilai koefisien determinasi sebesar $11 \%$
\end{abstract}

Kata Kunci : e-Commerce, Lingkungan Eksternal, UMKM 


\section{PENDAHULUAN}

Pemanfaatan teknologi e-Commerce dapat dirasakan oleh konsumen (business to consumer) maupun pelaku bisnis (business to business). Pemanfaat teknologi e-Commerce oleh pelaku bisnis memberikan nilai positif dan nilai negatif yang mana adanya pengaruh antara dua variabel yang mempengaruhi persepsi konsumen dalam penggunaan $e$ Commerce. Kepercayaan konsumen dan pelaku bisnis terhadap e-Commerce cenderung rendah sehingga sikap tersebut merupakan salah satu faktor yang mempengaruhi sistem pemasaran tradisional (Mumtahana, et.al, 2017)

Salah satu sistem promosi dalam pemasaran produk yang tidak lepas dari kemajuan penggunaan internet dalam dunia bisnis saat ini dikenal dengan E-marketplace. E-marketplace adalah sebuah sistem informasi antar organisasi dimana pembeli dan penjual di pasar mengkomunikasikan informasi tentang harga, produk dan mampu menyelesaikan transaksi melalui saluran komunikasi elektronik. Suatu e-Marketplace merepresentasikan suatu struktur sosial, konsep ekonomi pasar, dan penggunaan teknologi. e-Marketplace dapat memberikan peluang untuk melakukan bisnis dan melaksanakan transaksi melalui saluran elektronik, biasanya pada platform yang berbasiskan internet (Marco, et.al, 2017).

Dilansir dari surat kabar yang ditulis dalam koran "Kedaulatan Rakyat" tanggal 21 Oktober 2018 halaman 7. Berdasarkan data yang diperoleh dari hasil sosialisasi Ibu Septriana Tangkary selaku Direktur Informasi dan Komunikasi Perekonomian \& Maritim Ditjen Informasi dan Komunikasi Pulik dengan tema "Belanja \& Jualan Online: Murah, Cepat \& Aman" didapatkan data bahwasannya Indonesia akan menjadi salah satu negara ekonomi digital terbesar di wilayah Asia dengan estimasi transaksi e-Commerce mencapai 130 Milyar Dolar. Akan tetapi baru $8 \%$ atau sebanyak 3,79 juta pelaku UMKM di Indonesia dari hampir 60 juta pelaku UMKM yang menggunakan e-Commerce dalam melakukan pemasaran produknya dan bergabung dengan marketplace yang ada di
Indonesia seperti blibli.com, shopee, tokopedia dan lain-lainnya (Permana, 2018).

Selain itu berdasarkan data yang telah ditulis pada berita web gudeg.net pada hari Rabu, 03 april 2019 telah disampaikan oleh Kabag Pengawasan Industri Keuangan Non Bank (IKNB) Pasar Modal dan Efek OJK (Otoritas Jasa Keuangan) DIY Noor Hafid dimana memberikan penjelasan tentang masalah permodalan yang dihadapi oleh UMKM saat acara UMKM Jogja Go Digital. Di acara tersebut juga dijelaskan bahwasannya ada Fintech atau pendanaan Gotong Royong Online yang diharapkan untuk membantu UMKM di Yogyakarta untuk melebarkan sayapnya sehingga dengan mudah menjalankan usahanya. Pada saat yang bersamaan Kepala Dinas (Kadis) Koperasi dan UMKM DIY Srie Nurkyatsiwi menutirkan sepanjang akhir tahun 2018 pihak telah mendata sekitar 258 ribu UMKM yang berada di DIY. Data yang didapatan berdasarkan Data Pusat Layanan Usaha Terpadu (PLUT)ada sekita 3000 lebih para pelaku usaha yang sudah memanfaatkan pemasaran via internet. Jumlah sebanyak itu masih banyak sebagian dari para pelaku yang belum melakukan sistem pemasaran secara $e$ Commerce atau melalu internet Kesimpulan berdasarkan data yang dituliskan maka dapat diketahui bahwasannya sebanyak 255 ribu UMKM yang belum memanfaatkan pemasaran secara online atau masih sekitar $2 \%$ para pelaku yang sudah memanfaatkan $e$-Commerce (Rahman, 2019).

Jumlah UMKM kerajinan di Kota Yogyakarta menurut (Disperindag, 2019) berdasarkan data yang didapat dari Dinas Perindustrian dan Perdagangan (Disperindag) Kota Yogyakarta yang terdata secara keseluruhan UMKM kerajinan sebanyak 1.895. Berdasarkan data pada website UMKM Kota Yogyakarta dengan klasifikasi bidang kerajinan didapatkan data sebanyak 453 UMKM yang tercatat di website tersebut, sehingga berdasarkan data tersebut banyak UMKM yang belum mendaftarkan usahanya dalam website sebanyak 1442 UMKM atau sekitar $76 \%$ UMKM yang belum memanfaatkan e-Commerce sebagai pemasaran produknya. Dengan persentase sebagian para pelaku UMKM yang belum 
menggunakan sistem pemasaran secara $e$ Commerce atau pemasaran melalui internet terjadi dikarenakan adanya faktor penghambat baik dari lingkungan internal maupun eksternal yang menjadi permasalahan UMKM.

Berdasarkan observasi literatur yang didapatkan dari hasil wawancara tentang faktor-faktor lingkungan bisnis online yang dialami oleh UMKM ada beberapa faktor yang mempengaruhi hambatan dari lingkungan internal dan lingkungan eksternal pada pengguanaan $e$-Commerce. Menurut penelitian yang telah dilakukan oleh (Hanum \& Sinarasri, 2017) menjelaskan untuk mengetahui dan menganalisis pengaruh faktor teknologi, organisasional, lingkungan dan individual terhadap adopsi e-Commerce terhadap kinerja UMKM. Sedangkan penelitian yang dilakukan oleh (Govindaraju, et.al., 2012) menjelaskan beberapa faktor hambatan dalam penggunaan e-Commerce dalam UMKM. Sehingga banyak UMKM yang belum bisa mengatasi masalah hambatan dalam penggunaan e-Commerce dalam menunjang kesuksesan usaha UMKM. Menurut (Setyowati, 2015) adanya pengaruh lingkungan eksternal kurang direspons kurang baik dan bahkan dijadikan sebagai ancaman untuk menentukan keunggulan bersaing dalam memenuhi kebutuhan konsumen serta pemanfaatan teknologi informasi yang menunjang pemasaran produk UMKM tersebut.

\section{e-Business dan e-Commerce}

Electronic Business merupakan organisasi yang menghubungkan critical business system secara langsung kepada konsumen, karyawan, supplier, dan distributor dengan menggunakan web (berbentuk internet, intranet dan ekstranet) (Melati, 2017). Electronic Commerce (e-Commerce) merupakan pembelian atau penjualan barang atau jasa dengan menggunakan media eletronik. Marketplace menurut Menurut Boris Wertz dan Angela Tran Kingyens marketplace didefinisikan sebagai pasar online atau salah satu jenis situs e-Commerce yang menghubungkan penyedia produk atau jasa (penjual) dengan yang mencari untuk membeli produk atau layanan (pembeli). Demikian online marketplace (pasar online) menciptakan efisiensi dipasar lainnya (offline) yang mempermudah antara penjual dengan pembeli. (Rahman,et.al., 2017)

\section{Segmentasi Pemasaran}

Segmentasi pemasaran merupakan dasar untuk mengetahui bahwa setiap pasar terdiri dari beberapa segmen yang berbeda-beda. Setiap kebutuhan yang ingin dicapai setiap perusahaan berbeda-beda sehingga akan lebih baik jika perusahaan tersebut dapat menemukan cara baru untuk mengadakan segmentasi pasar antara lain adalah : Segmentasi geografis, segmentasi demografis, segmentasi psikografis dan segmentasi prilaku (Rohmanudin, 2017).

\section{UMKM}

Definisi UMKM menurut UndangUndang Republik Indonesia N0.20 Tahun 2008 tentang UMKM Pasal 1 dari UU dinyatakan bahwa Usaha Mikro adalah usaha produktif milik perorangan atau bada usaha perorangan. Adapun faktor yang mempengaruhi pretasi perindustrian kecil diantaranya yaitu pengaruh faktor lingkungan internal dan lingkungan eksternal. Lingkungan internal dipengaruhi oleh Sumber Daya Manusia (SDM), produk, pemasaran dan pendapatan. Sedangkan, lingkungan eksternal dipengaruhi oleh teknologi, konsumen, pesaing dan kebijakan pemerintah yang mana pengaruh lingkungan keduanya mempengaruhi produktivitas pemasaran yang digunakan oleh pemilik usaha.

\section{Analisis Regresi Linear}

(Ghozali, 2013) analisis regresi linear adalah suatu metodologi statistik untuk memprediksi nilai dari suatu variabel respon (variabel dependen) terhadap korelasi dari satu atau lebih nilai variabel prediktor (variabel independen). Dalam analisis regresi, selain mengukuur kekuatan hubungan antara dua variabel atau lebih, juga menunjukan arah hubungan antara variabel dependen dan variabel independen. Asumsi yang harus dipenuhi ketika akan melakukan uji regresi yaitu; uji normalitas, linearitas, multikolinearitas, dan heteroskedastisitas

\section{METODE PENELITIAN}

Objek penelitian melakukan penyebaran kuisioner sebanyak 100 UMKM kerajinan di Kota Yogyakarta yang belum memanfaatkan $e$ Commerce atapun yang sudah memanfaatkan e-Commerce tetapi belum bergabung dengan 
marketplace. adapun subjek penelitian ini adalah pemilik UMKM kerajinan di Kota Yogyakarta. Definisi variabel yang digunakan dalam penelitian ini dapat dilihat pada Tabel 1.

Berdasarkan model analisis yang digunakan dalam penelitian, maka variabel yang diteliti sebagai berikut :

1. Variabel terikat, adalah variabel yang dipengaruhi oleh variabel lain. Variabel terikat dalam penelitian ini adalah

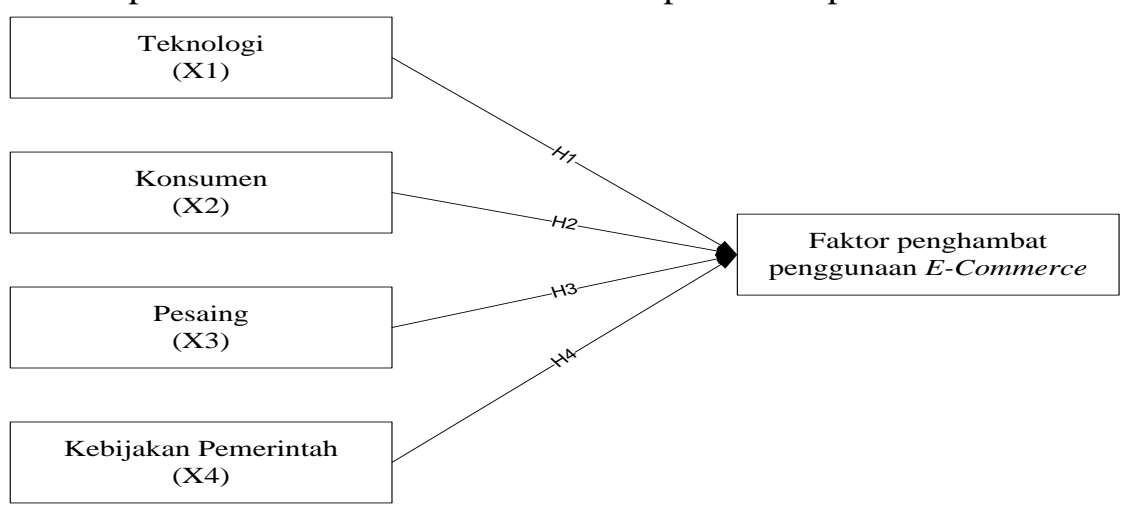

Gambar 1 Model Konseptual hambatan penggunaan e-Commerce yang dinotasikan sebagai $\mathrm{Y}$

2. Variabel bebas, adalah variabel yang mempengaruhi variabel lain. Variabel bebas yang digunakan dalam penelitian ini adalah faktor lingkungan teknologi $\left(\mathrm{X}_{1}\right)$, konsumen $\left(\mathrm{X}_{2}\right)$, pesaing $\left(\mathrm{X}_{3}\right)$ dan kebijakan pemerintah $\left(\mathrm{X}_{4}\right)$.

Model konseptual pada penelitian ini dapat dilihat pada Gambar 1.

\section{HASIL DAN PEMBAHASAN}

\section{Uji Reliabitas dan Uji Validitas}

1. Uji Validitas dan Uji Reliabilitas Teknologi $\left(\mathrm{X}_{1}\right)$

Hasil dari uji validitas dan reliabilitas variable Teknologi dapat dilihat pada Tabel 2

2. Uji Validitas dan Uji Reliabilitas Konsumen $\left(\mathrm{X}_{2}\right)$

Uji validitas dan uji reliabilitas konsumen $\left(\mathrm{X}_{2}\right)$ dapat dilihat pada Tabel 3

3. Uji Validitas dan Uji Reliabilitas Pesaing $\left(\mathrm{X}_{3}\right)$

Uji validitas dan uji reliabilitas konsumen

$\left(\mathrm{X}_{3}\right)$ dapat dilihat pada Tabel 4
4. Uji Validitas dan Uji Reliabilitas Kebijakan Pemerintah $\left(\mathrm{X}_{4}\right)$

Uji validitas dan uji reliabilitas konsumen $\left(\mathrm{X}_{4}\right)$ dapat dilihat pada Tabel 5

5. Uji Validitas dan Uji Reliabilitas Faktor Penghambat Penggunaan e-Commerce (Y)

Hasil dari uji validitas dan reliabilitas Faktor Penghambat Penggunaan $e$ Commerce (Y) dapat dilihat pada Tabel 6 
Syifa Fitriani, Melati Medinah, Utaminingsih Linarti

Submitted: 07/10/2020; Revised: 09/10/2020; Accepted: 12/10/2020; Published: 29/12/2020

Tabel 1 Pengembangan kuisioner

\begin{tabular}{|c|c|c|}
\hline No & Faktor & Definisi Faktor \\
\hline 1. & Teknologi & $\begin{array}{l}\text { keseluruhan saranan untuk } \\
\text { menyediakan barang-barang } \\
\text { yang diperlukan bagi } \\
\text { kelangsungan dan } \\
\text { kenyamanan hidup manusia. } \\
\text { Adapun indikator teknologi. }\end{array}$ \\
\hline 2. & Konsumen & $\begin{array}{l}\text { Faktor konsumen atau } \\
\text { pelanggan adalah salah satu } \\
\text { kelompok potnsial yang } \\
\text { menerima output dari produk } \\
\text { yang dihasilkan perusahaan. }\end{array}$ \\
\hline
\end{tabular}

3. Pesaing

\section{Kebijakan} Pemerintah
Pesaing adalah perusahaanperusahaan yang menawarkan produk dengan tipe dan karakteristik yang relatif sama

Faktor pemerintah memiliki peranan yang sangat penting untuk menunjang suksesnya keamanan dan menunjang fasilitas yang akan diterima pelanggan

Item

Pendaftaran online pada aplikasi e-Commerce rumit

Kesulitan saya dalam menginstal aplikasi

Sinyal internet yang tidak stabil

Biaya provider jaringan (pulsa dan kouta) mahal

Tingkat kepercayaan terhadap keamanan yang rendah pada $e$-Commerce.

Kesulitan merespon pertanyaan konsumen

Peluang konsumen dalam membeli barang secara konvensional lebih besar dibandingkan online $(e-$ Commerce)

Kesulitan melayani keluhan/ komplain konsumen secara online (e-Commerce)

Kesulitan berinteraksi dengan konsumen secara online (e-Commerce)

Kemungkinan penipuan dilakukan oleh konsumen secara online (e-Commerce)

Keraguan saya menjual online karena munculnya persaingan yang tinggi

Banyaknya pesaing yang telah melakukan penjualan dengan media online (e-Commerce) Persaingan harga dengan pedagang lain $(e-$ Commerce) membuat saya tidak percaya diri

Penilaian produk konsumen mempengaruhi persaingan penjualan online Persaingan dengan penjual lain mengenai respon dengan konsumen

Kebijakan pajak dari pemerintah terkait dengan pemasaran online memberatkan saya dan konsumen

Tidak ada pembinaan pemerintah tentang penjualan online (e-Commerce)

Tidak ada bantuan dana dari pemerintah untuk megembangkan bisnis dengan teknologi online untuk e-Commerce

Tidak ada jaminan kemanan dari pemerintah tentang jual beli online (e-Commerce)

Tidak ada peraturan yang memberikn penjualan media online atau dengan $e$-Commerce

Ketegasan peraturan pemerintah tentang hukuman plagiarisme (penjiplakan) foto/dokumentasi produk pada penggunaan $e$-Commerce

Tabel 2 Hasil Validitas Dan Reliabilitas Variabel Teknologi $\left(\mathrm{X}_{1}\right)$

\begin{tabular}{cccccc}
\hline Pernyataan & $\begin{array}{c}\mathbf{R} \\
\text { Hitung }\end{array}$ & R Tabel & Ket & $\begin{array}{c}\text { Nilai Cronbach's } \\
\text { Alpha }\end{array}$ & Ket \\
\hline Tek $_{1}$ & 0,574 & & Valid & & Reliabel \\
Tek $_{2}$ & 0,440 & & Valid & & \\
Tek $_{3}$ & 0,316 & 0,1966 & Valid & 0,657 & \\
Tek $_{4}$ & 0,311 & & Valid & & \\
Tek $_{5}$ & 0,413 & & Valid & & \\
\hline
\end{tabular}


Syifa Fitriani, Melati Medinah, Utaminingsih Linarti

Submitted: 07/10/2020; Revised: 09/10/2020; Accepted: 12/10/2020; Published: 29/12/2020

Tabel 3 Hasil Validitas Dan Reliabilitas

\begin{tabular}{|c|c|c|c|c|c|}
\hline Pernyataan & $\begin{array}{c}\text { R } \\
\text { Hitung }\end{array}$ & R Tabel & Ket & $\begin{array}{c}\text { Nilai Cronbach's } \\
\text { Alpha }\end{array}$ & Ket \\
\hline Kons $_{1}$ & 0,587 & \multirow{4}{*}{0,1966} & Valid & \multirow{4}{*}{0,776} & \multirow{4}{*}{ Reliabel } \\
\hline Kons2 & 0,442 & & Valid & & \\
\hline Kons $_{3}$ & 0,669 & & Valid & & \\
\hline Kons4 & 0,625 & & Valid & & \\
\hline
\end{tabular}

Tabel 4 Hasil Validitas Dan Reliabilitas Variabel Pesaing $\left(\mathrm{X}_{3}\right)$

\begin{tabular}{|c|c|c|c|c|c|}
\hline Pernyataan & $\begin{array}{c}\mathbf{R} \\
\text { Hitung }\end{array}$ & R Tabel & Ket & Nilai Cronbach's Alpha & Ket \\
\hline $\mathrm{Pes}_{1}$ & 0,522 & & Valid & & \\
\hline $\mathrm{Pes}_{2}$ & 0,424 & & Valid & & \\
\hline $\mathrm{Pes}_{3}$ & 0,620 & 0,1966 & Valid & 0,705 & Reliabel \\
\hline $\mathrm{Pes}_{4}$ & 0,316 & & Valid & & \\
\hline $\mathrm{Pes}_{5}$ & 0,452 & & Valid & & \\
\hline
\end{tabular}

Tabel 5 Hasil Validitas Dan Reliabilitas Variabel Kebijakan Pemerintah $\left(\mathrm{X}_{4}\right)$

\begin{tabular}{ccccc}
\hline Pernyataan & $\begin{array}{c}\text { R } \\
\text { Hitung }\end{array}$ & R Tabel & Ket & Nilai Cronbach's Alpha \\
\hline $\mathrm{KP}_{1}$ & 0,572 & & Valid & \\
$\mathrm{KP}_{2}$ & 0,758 & 0,1966 & Valid & Reliabel \\
$\mathrm{KP}_{3}$ & 0,365 & & Valid & Valid \\
$\mathrm{KP}_{4}$ & 0,683 & Valid & \\
$\mathrm{KP}_{5}$ & 0,646 & & & \\
\hline
\end{tabular}

Tabel 6 Hasil Validitas Dan Reliabilitas Faktor Penghambat Penggunaan e-Commerce (Y)

\begin{tabular}{cccccc}
\hline Pernyataan & $\begin{array}{c}\text { R } \\
\text { Hitung }\end{array}$ & R Tabel & Ket & $\begin{array}{c}\text { Nilai Cronbach's } \\
\text { Alpha }\end{array}$ & Ket \\
\hline $\mathrm{Y}_{1}$ & 0,463 & & Valid & & Reliabel \\
$\mathrm{Y}_{2}$ & 0,660 & 0,1966 & Valid & 0,619 & \\
$\mathrm{Y}_{3}$ & 0,223 & & Valid & & \\
\hline
\end{tabular}

\section{Uji Asumsi Klasik}

1. Uji Multikolonieritas

Tabel 7 Hasil Uji Multikolonieritas

\begin{tabular}{lcc}
\hline \multicolumn{1}{c}{ Variabel } & \multicolumn{2}{c}{ Collinearity Statistics } \\
& Tolerance & VIF \\
\hline Teknologi $\left(\mathrm{X}_{1}\right)$ & 0,677 & 1,476 \\
Konsumen $\left(\mathrm{X}_{2}\right)$ & 0,788 & 1,269 \\
Pesaing $\left(\mathrm{X}_{3}\right)$ & 0,779 & 1,283 \\
Kebijakan Pemerintah $\left(\mathrm{X}_{4}\right)$ & 0,911 & 1,098 \\
\hline
\end{tabular}

2. Uji Heteroskedastisits

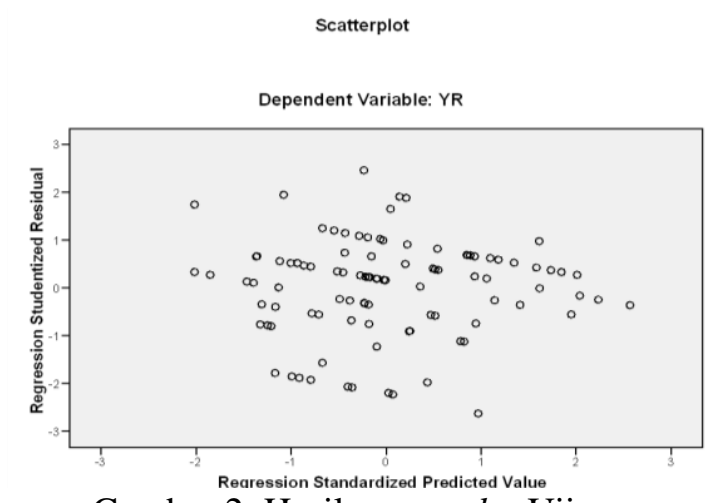

Gambar 2 Hasil scatterplot $\mathrm{Uji}$

Heteroskedastisitas 


\section{Uji Normalitas}

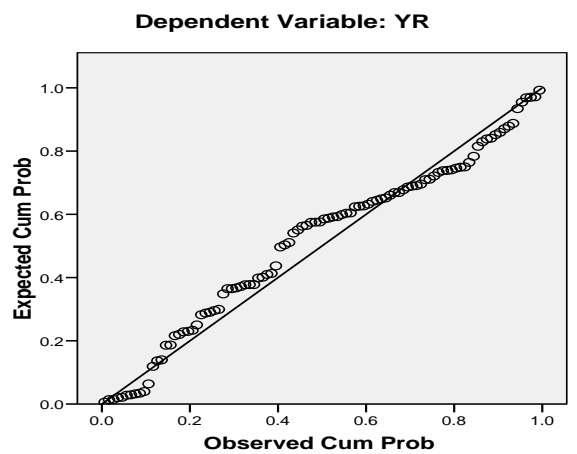

Gambar 3 Grafik P-P Plot of Regression

Grafik menunjukkan bahwa data berditribusi normal, untuk membuktikan atau mendukung hasil uji normalitas dengan grafik perlu dilakukan uji normalitas Kolmogorov Smirnov dengan SPSS. Hasil uji Kolmogorov Smirnov dapat dilihat pada tabel 8

Tabel 8 One-Sample Kolmogorov Smirnov

\begin{tabular}{|c|c|c|}
\hline & & $\begin{array}{l}\text { Unstandardized } \\
\text { Residual }\end{array}$ \\
\hline $\mathbf{N}$ & & 100 \\
\hline \multirow{2}{*}{$\begin{array}{l}\text { Normal } \\
\text { Parameters }(a, b)\end{array}$} & Mean &, 0000000 \\
\hline & Std. Deviation & ,71571927 \\
\hline \multirow{3}{*}{$\begin{array}{l}\text { Most Extreme } \\
\text { Differences }\end{array}$} & Absolute &, 114 \\
\hline & Positive & 076 \\
\hline & Negative &,- 114 \\
\hline \multirow{2}{*}{\multicolumn{2}{|c|}{$\begin{array}{l}\text { Kolmogorov-Smirnov } Z \\
\text { Asymp. Sig. (2-tailed) }\end{array}$}} & 1,137 \\
\hline & & ,151 \\
\hline
\end{tabular}

\section{Uji Regresi Berganda}

1. Persaaan Regresi

Persamaan resgresi linear berganda dimaksudkan untuk menguji pengaruh dua atau lebih variabel independen terhadap variabel dependen. Adapun persamaan rumus yaitu:

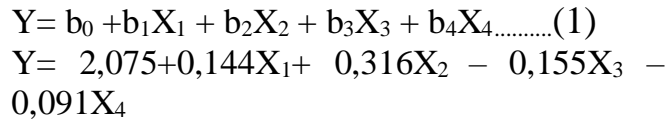

2. Uji Koefisien Determinasi

Tabel 9 Uji Koefisien Determinasi

\begin{tabular}{ccccc}
\hline Model & $\boldsymbol{R}$ & $\begin{array}{c}\boldsymbol{R} \\
\text { Square }\end{array}$ & $\begin{array}{c}\text { Adjusted } \\
\boldsymbol{R} \text { Square }\end{array}$ & $\begin{array}{c}\text { Std. Error of } \\
\text { the Estimate }\end{array}$ \\
\hline 1 & $0,341^{\mathrm{a}}$ & 0,116 & 0,079 & 0,73063
\end{tabular}

Besarnya nilai $\mathrm{R}^{2}$ sebesar 0,116 atau 11 $\%$. Angka tersebut mengandung arti bahwa variabel teknologi, konsumen, pesaing, dan kebijakan pemerintah berpengaruh terhadap penggunaan $e$ Commerce sebesar $11 \%$. Sisanya $89 \%$ dijelaskan atau dipengaruhi oleh variabel lain yang tidak diteliti.

3. Uji F ( f tabel $=2,47$ )

Hasil pengujian untuk Uji $\mathrm{F}$ dengan $\mathrm{f}_{\text {tabel }}=$ 2,47 dapat dilihat pada Tabel 10 . Pengujian data statistik $F$ didapatkan bahwa $\mathrm{F}$ hitung $>\mathrm{F}$ tabel $(3,119>2,47)$ dan nilai signifikansi $\mathrm{P}$ value $<0,05$ $(0,019<0.05)$. maka $\mathrm{H}_{0}$ ditolak sehingga variabel independen mempunyai pengaruh yang signifikan terhadap variabel hambatan penggunaan e-Commerce $(\mathrm{Y})$.

4. $\quad$ Uji T $(\mathrm{t}$ tabel $=1,98)$

Uji $\mathrm{T}$ yang telah dilakukan dengan $\mathrm{t}_{\text {tabel }}$ $=1,98$ dapat dilihat hasilnya pada Tabel 11. Berdasarkan tabel dijelaskan bahwa pengujian signifikansi uji statistik $t$ digunakan untuk mengetahui apakah variabel independent berpengaruh signifikan atau tidak berpengaruh signifikan terhadap variabel dependent dengan cara melakukan uji signifikansi dan uji t. Dalam penelitian ini menggunakan signifikansi level 0,05 ( $\alpha=$ $5 \%)$ untuk faktor teknologi, konsumen, pesaing dan kebijakan pemerintah. Jika $t$ hitung < $\mathrm{t}$ tabel, maka variabel independent secara parsial tidak berpengaruh terhadap variabel dependent. Sedangkan jika $\mathrm{t}$ hitung $>\mathrm{t}$ tabel, maka variabel independent secara parsial berpengaruh terhadap variabel dependent (hipotesis ditolak). 
Syifa Fitriani, Melati Medinah, Utaminingsih Linarti

Submitted: 07/10/2020; Revised: 09/10/2020; Accepted: 12/10/2020; Published: 29/12/2020

Tabel 10. Uji F

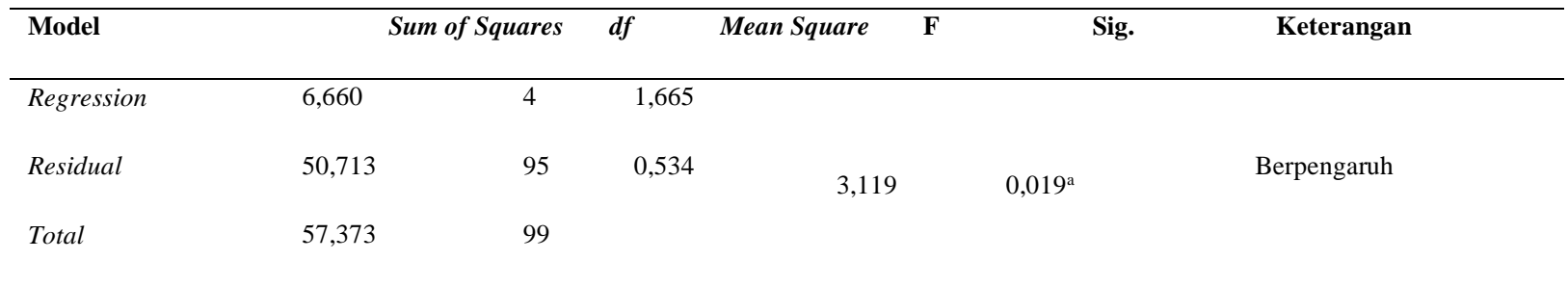

Tabel 11. Uji T

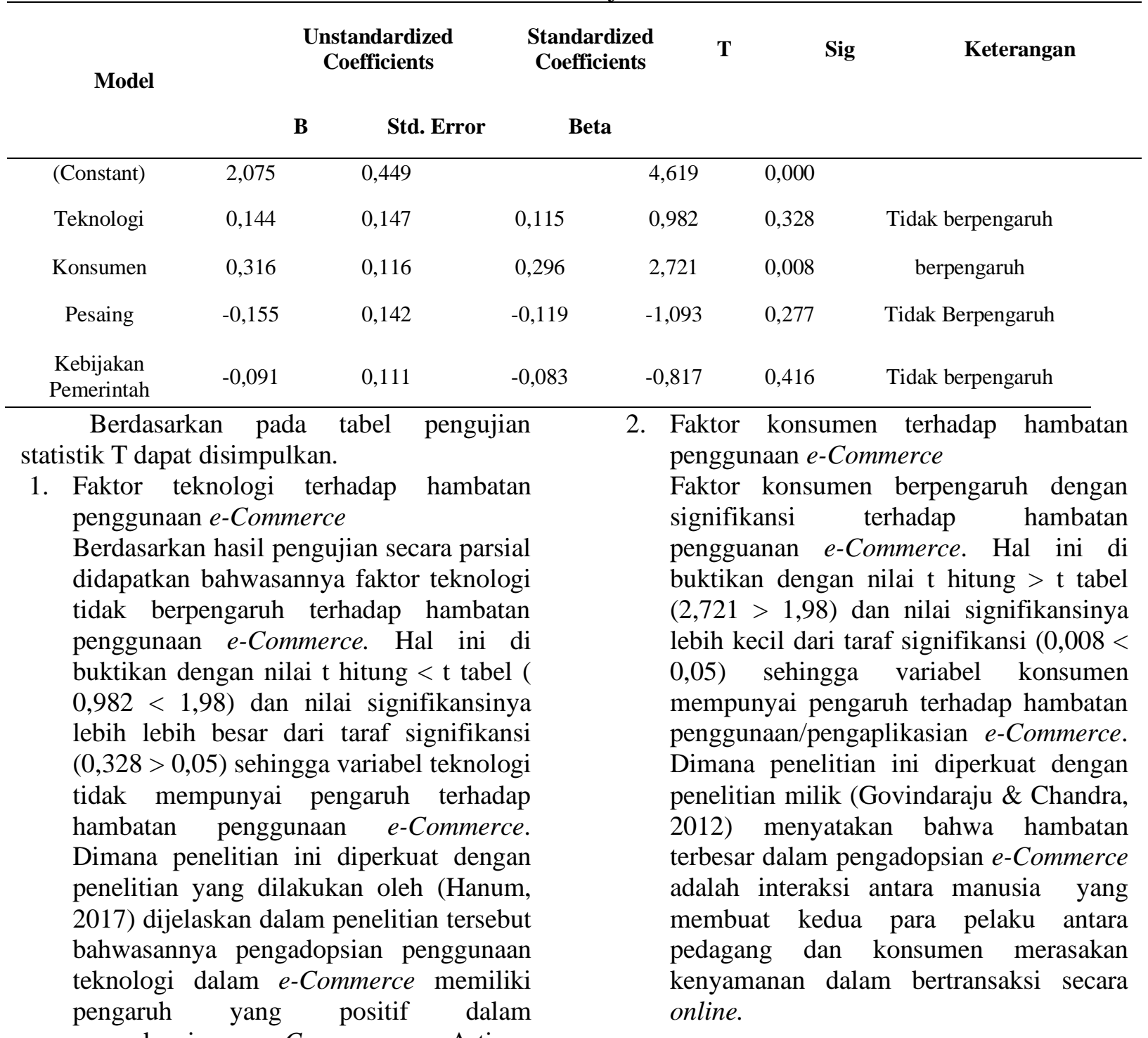
pengadopsian e-Commerce. Artinya penggunaan teknologi dalam penggunaan e-Commerce bukan menjadi salah satu hambatan dalam meningkatkan pemasaran produk bagi para pelaku usaha UMKM.

3. Faktor pesaing terhadap hambatan penggunaan $e$-Commerce

Faktor pesaing tidak berpengaruh dengan signifikansi terhadap hambatan penggunaan e-Commerce. Hal ini di buktikan dengan nilai $\mathrm{t}$ hitung $<\mathrm{t}$ tabel $(1,093<1,98)$ dan nilai signifikansinya lebih besar dari taraf signifikansi $(0,277>$ 
0,05) sehingga variabel pesaing tidak memiliki pengaruh terhadap hambatan penggunaan e-Commerce. Artinya persaingan menggunakan e-Commerce memberikan dapak positif untuk menunjang perkembangan UMKM. Adapun penelitian ini di perkuat dengan penelitian milik (Hanum, 2017). Salah satu implementasi teknologi dalam meningkatkan persaingan bisnis adalah dengan menggunakan e-Commerce, dengan menggunakan e-Commerce perusahaan mendapatkan manfaat yang dijadikan keunggulan dalam bersaing sehingga perusahaan dapat meningkatkan layanan yang terbaik dan tercepat bagi pelanggannya.

4. Faktor kebijakan pemerintah terhadap hambatan penggunaan $e$-Commerce

Faktor kebijakan pemerintah tidak berpengaruh dengan signifikansi terhadap hambatan penggunaan e-Commerce. Hal ini di buktikan dengan nilai $\mathrm{t}$ hitung $<\mathrm{t}$ tabel $(0,817<1,98)$ dan nilai signifikansinya lebih besar dari taraf signifikansi $(0,416>0,05)$ sehingga variabel kebijakan pemerintah tidak memiliki pengaruh terhadap hambatan penggunaan e-Commerce. Hasil penelitian ini diperkuat dengan penelitian milik (Hernando, 2013) dimana hasilnya menunjukkan bahwa kebijakan pemerintah dan dukungan perusahaan pengembang salah satu cara untuk mesukseskan pengadopsian e-Commerce di Indonesia. Sehingga kesimpulan kebijakan pemerintah bukan menjadi salah satu hambatan dalam pengadopsian e-Commerce dikarenakan selama ini pemerintah sudah memberikan dukungan yang kontradiktif untuk perkembangan bagi UMKM.

\section{KESIMPULAN DAN SARAN \\ KESIMPULAN}

Bedasarkan hasil penelitian dan pembahasan mengenai faktor-faktor lingkungan eksternal yang mempengaruhi penghambat penggunaan e-Commerce pada UMKM kerajinan di Kota Yogyakarta dapat ditarik kesimpulan bahwa faktor yang mempengaruhi hambatan penggunaan $e$ Commerce pada UMKM kerajinan di Kota 109
Yogyakarta adalah faktor konsumen $\left(\mathrm{X}_{2}\right)$, setelah dilakukan pengujian secara simultan didapatkan hasil variabel independent yang terdiri dari faktor teknologi $\left(\mathrm{X}_{1}\right)$, faktor konsumen $\left(\mathrm{X}_{2}\right)$, faktor pesaing $\left(\mathrm{X}_{3}\right)$ dan faktor kebijakan pemerintah $\left(\mathrm{X}_{4}\right)$ secara bersamasama berpengaruh terhadap hambatan penggunaan e-Commerce pada UMKM kerajinan di Kota Yogyakarta dengan nilai $\mathrm{R}^{2}$ sebesar $11 \%$ z.

\section{SARAN}

Berdasarkan hasil penelitian yang didapatkan, maka saran yang dapat diberikan adalah:

1. Penelitian ini didapatkan hasil koefisien determinasi yang kecil yaitu sebesar $11 \%$ sehingga masih ada faktor lain yang mempengaruhi hambatan penggunaan $e$ Commerce sebesar $89 \%$. Sehingga harapannya untuk penelitian selanjutnya mengembangkan penelitian ini dengan mencari faktor lainnya.

2. Adanya penelitian selanjutnya yang meneliti lebih spesifikasi lagi untuk faktor konsumen yang menghambat penggunaan e-Commerce di lingkungan internal dan eksternal terhadap UMKM kerajinan di Kota Yogyakarta.

\section{DAFTAR PUSTAKA}

Athaillah, Hamzah, A., \& Masbar, R. (2016). klasifikikasi umkm. Faktor-Faktor Yang Mempengaruhi Pertumbuhan Ekonomi Provinsi Aceh, 56.

Baratullah, A. H., \& Prasetyo, T. (2005). Bisnis E-Commerce Study System Keamanan dan Hukum Indonesia. Yogyakarta: Pustaka Pelajar.

Disperindag. (2019). UMKM Kota Jgja. Dipetik 2019, dari http://umkm.jogjakota.go.id/direktori2/ group.php?mod=ci\&cabang_industri= Kerajinan+dan+Umum

Ferrinadewi, E. (2008)."Merek \& Psiklogi Konsumen (Implikasi pada Strategi Pemasaran)". Yogyakarta: Graha Ilmu.

Ghozali, P. H. (2018). "Aplikasi Analisis Multivariate Dengan Program IBM SPSS 26. Semarang": Universitas Diponegoro.

Govindaraju, R., \& Chandra, D. R. (2012)."Analysis of Level and Barriers 
Syifa Fitriani, Melati Medinah, Utaminingsih Linarti

Submitted: 07/10/2020; Revised: 09/10/2020; Accepted: 12/10/2020; Published: 29/12/2020

of E-Commerce Adoption by Indonesian Small, Medium, and Micro Enterprises (SMMEs)", 14.

Hanum, A. N., \& Sinarasri, A. (2017). "Analisis Faktor-Faktor Yang Mempengaruhi Adopsi E Commerce Dan Pengaruhnya Terhadap Kinerja Umkm (Studi Kasus Umkm Di Wilayah Kota Semarang)", 15.

Hendri, E. (2013)."Analisis Faktor-Faktor Perilaku Konsumen Yang Mempengaruhi Keputusan Beli Mahasiswa Menempuh Kuliah Di Fakultas Ekonomi Universitas PGRI Palembang". Palembang: Universitas PGRI Palembang.

Marco, R., \& Ningrum, B. T. (2017)."Analisis Sistem Informasi E-Marketplace Pada Usaha Kecil Menengah (Ukm) Kerajinan Bambu", 53.

Melati, K. R. (2017)."Perancangan dan Implementasi Perencanaan Bisnis dan Strategi Promosi bagi Kelompok Rintisan Usaha Mandiri Sanggar Batik Jenggolo dan Sear Arum di Kota Yogyakarta, 235.

Mumtahana, H. A., Nita, S., \& Tito, A. W. (2017). "Pemanfaatan Web ECommerce untuk Meningkatkan Strategi Pemasaran", 15.

Permana, D. (2018). Pemasaran produk terhadap UMKM. Yogyakarta: Kedaulatan Rakyat.

Prawirosentono, D. S. (2002)."Pengantar Bisnis Modern: Studi Kasus Indonesia dan Analisis Kuantitatif" . Jakarta: Bumi Aksara.

Rahman. (2019). Bantu UMKM, OJK DIY Sarankan Penggunaan Kredit Fintech. Yogyakarta: Gudeg.nt.

Rahmidani, R. (2015). "Penggunaan ECommerce Dalam Bisnis Sebagai Sumber Keunggulan Bersaing Perusahaan", 352.

Rohmanudin. (2017).Analisis Strategi Pemasaran Dalam Meningkatkan Daya Saing (Studi Pada Industri Mebel di Kecamatan Wayhalim Kota Bandar Lampung), 404.
Sandjaja, I. E., \& Purnamasari, D. (2017)."Perancangan Kuisioner Survei" Galangan, 33.

Setyowati, N. W. (2015)."Pengaruh Lingkungan Eksternal dan Lingkungan Internal Terhadap Keunggulan Bersaing Pada Industri Kecil dan Menengah Di Bandung" Jawa Barat, 26.

Sugiyono, P. (2015)."Metode Penelitian Pendidikan Kuatitatif, Kualitatif dan $R \& D^{\prime \prime}$. Bandung: Alfabeta.

Supranto, J. (2008). "Statistik Teori dan Aplikasi (Edisi ketujuh Jilid kesatu)". Jakarta: Erlangga. 